\title{
Performance Analysis of Shell \& Tube Type Heat Exchanger under the Effect of Varied Operating Conditions
}

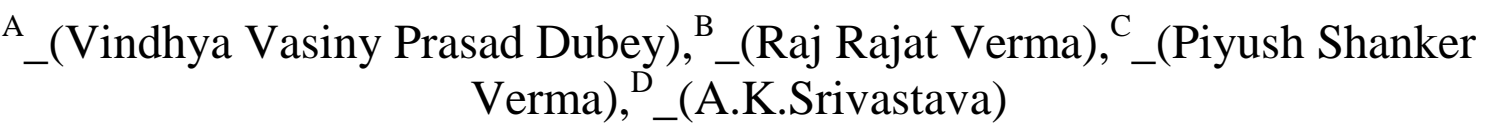

A) UG Student, Mechanical Engineering Department, Shri Ramswaroop Memorial College Of Engineering \& Management, Lucknow.

B) UG Student, Mechanical Engineering Department, Shri Ramswaroop Memorial College Of Engineering \& Management, Lucknow.

C) UG Student, Mechanical Engineering Department, Shri Ramswaroop Memorial College Of Engineering \& Management, Lucknow.

D) Professor \& Head Of Department, Mechanical Engineering Department, Shri Ramswaroop Memorial College Of Engineering \& Management, Lucknow.

\begin{abstract}
This paper consists of extensive thermal analysis of the effects of severe loading conditions on the performance of the heat exchanger. To serve the purpose a simplified model of shell and tube type heat exchanger has been designed using kern's method to cool the water from $55^{\circ} \mathrm{C}$ to $45^{\circ} \mathrm{C}$ by using water at room temperature. Then we have carried out steady state thermal analysis on ANSYS 14.0 to justify the design. After that the practical working model of the same has been fabricated using the components of the exact dimensions as derived from the designing. We have tested the heat exchanger under various flow conditions using the insulations of aluminium foil, cotton wool, tape, foam, paper etc. We have also tested the heat exchanger under various ambient temperatures to see its effect on the performance of the heat exchanger. Moreover we have tried to create the turbulence by closing the pump opening and observed its effect on its effectiveness. All these observations along with their discussions have been discussed in detail inside the paper.
\end{abstract}

Key words: shell and tube type heat exchanger; kern's method; ANSYS 14.0; insulations; turbulence; effectiveness.

\section{Nomenclature}

$\mathrm{m}$

$\mathrm{C}_{\mathrm{p}}$

C

$\mathrm{t}$

t'

LMTD (or $\Delta \mathrm{T})$

Q

$\mathrm{U}\left(\right.$ or $\left.\mathrm{U}_{0}\right)$

A

ID

OD

1

$\mathrm{N}$

$\mathrm{D}_{\mathrm{b}}$

d

D

B

$\mathrm{P}_{\mathrm{r}}$

$\mathrm{R}_{\mathrm{e}}$

$\mathrm{Nu}$

$\mathrm{h}$

\section{Subscripts}

i

O

$\mathrm{t}$ mass flow rate of fluid $(\mathrm{kg} / \mathrm{second})$

specific heat of fluid $\left(\mathrm{J} / \mathrm{kg}-{ }^{\circ} \mathrm{C}\right)$

capacity rate of fluid $\left(\mathrm{W} /{ }^{\circ} \mathrm{C}\right)$

temperature of fluid as used in designing $\left({ }^{\circ} \mathrm{C}\right)$

experimental value of temperature of the fluid $\left({ }^{\circ} \mathrm{C}\right)$

Logarithmic Mean Temperature Difference $\left({ }^{\circ} \mathrm{C}\right)$

amount of heat transfer taking place (watts)

overall heat transfer coefficient $\left(\mathrm{w} / \mathrm{m}^{2}{ }^{\circ} \mathrm{c}\right)$

area of heat exchanger $\left(\mathrm{m}^{2}\right)$

inner diameter

outer diameter

length of heat exchanger (m)

number of tubes

tube bundle diameter $(\mathrm{mm})$

diameter of tubes $(\mathrm{mm})$

diameter of shell $(\mathrm{mm})$

baffle spacing $(\mathrm{mm})$

Prandtl number

Reynold's number

Nusselt number

heat transfer coefficient $\left(\mathrm{w} / \mathrm{m}^{2}{ }^{\circ} \mathrm{c}\right)$

inner surface parameter

outer surface parameter

tube side parameter 
Performance Analysis Of Shell \& Tube Type Heat Exchanger Under The Effect Of Varied ......

S

W

h

c

1,2

$\max$

Constants

$\mathrm{K}_{1}, \mathrm{n}_{1}$ shell side parameter

wall temperature parameter

hot fluid parameter

cold fluid parameter

for inlet and outlet respectively

maximum amount of the quantity

constants depending on the pitch and type of pass

\section{Introduction}

A shell and tube heat exchanger is a class of heat exchanger designs. It is the most common type of heat exchanger in oil refineries and other large chemical processes, and is suited for higher-pressure applications. As its name implies, this type of heat exchanger consists of a shell (a large pressure vessel) with a bundle of tubes inside it. One fluid runs through the tubes, and another fluid flows over the tubes (through the shell) to transfer heat between the two fluids. The set of tubes is called a tube bundle, and may be composed of several types of tubes: plain, longitudinally finned, etc. In this paper we are concerned about the performance analysis of shell and tube type heat exchanger under different loading conditions. To do the same we have first designed a shell and tube type heat exchanger to get the dimensions of the parts involved and thereafter fabrication and testing of the actual working model has been done to see the effects of various parameters on the performance of the heat exchanger. Some of the works reviewed for the purpose are as described below:

A.O. Adelaja, S. J. Ojolo and M. G. Sobamowo consider both the thermal and mechanical design of the E-type shell and tube heat exchanger with the aid of computer programming. It involves developing a simple user-friendly computer programme for the heat transfer calculations and ensures that the computational time is kept minimal. The algorithm is designed such that after the conditions for the thermal analysis are satisfied, the programme automatically proceeds to the mechanical design. The programme written in Visual Basic was tested using a model and the simulated result presented. Software has been developed for the thermal, hydraulic and mechanical design of a shell and tube heat exchanger using the Kern model[16] to evaluate the coefficient of heat transfer and the pressure drop. The interactive nature of the user-friendly, object oriented Visual Basic software enables it to first do the thermal-hydraulic design after which it proceeds to the mechanical module when all conditions are satisfied. Also changes in the conditions, parameters and geometry can be easily effected at any point in the design process. Drawings however can only be made after the mechanical design and not before it. The software will be useful for both industrial applications and educational purposes.

Yusuf Ali Kara and Ozbilen Guraras prepared a computer based design model for preliminary design of shell and tube heat exchangers with single phase fluid flow both on shell and tube side. The program determines the overall dimensions of the shell, the tube bundle, and optimum heat transfer surface area required to meet the specified heat transfer duty by calculating minimum or allowable shell side pressure drop. $\mathrm{He}$ concluded that circulating cold fluid in shell-side has some advantages on hot fluid as shell stream since the former causes lower shell-side pressure drop and requires smaller heat transfer area than the latter and thus it is better to put the stream with lower mass flow rate on the shell side because of the baffled space.

Rajagapal THUNDIL KARUPPA RAJ and Srikanth GANNE made the attempts to investigate the impacts of various baffle inclination angles on fluid flow and the heat transfer characteristics of a shell-and-tube heat exchanger for three different baffle inclination angles namely $0^{\circ}, 10^{\circ}$, and $20^{\circ}$. The simulation results for various shell and tube heat exchangers, one with segmental baffles perpendicular to fluid flow and two with segmental baffles inclined to the direction of fluid flow are compared for their performance. The shell side design has been investigated numerically by modelling a small shell-and-tube heat exchanger. The study is concerned with a single shell and single side pass parallel flow heat exchanger. The flow and temperature fields inside the shell are studied using non-commercial computational fluid dynamics software tool ANSYS CFX 12.1. For a given baffle cut of $36 \%$, the heat exchanger performance is investigated by varying mass flow rate and baffle inclination angle. From the computational fluid dynamics simulation results, the shell side outlet temperature, pressure drop, re-circulation near the baffles, optimal mass flow rate and the optimum baffle inclination angle for the given heat exchanger geometry are determined. It was concluded that the shell and tube heat exchanger with $20^{\circ}$ baffle inclination angle results in better performance compared to $10^{\circ}$ and $0^{\circ}$ inclination angles.

S. Noie Baghban, M. Moghiman and E. Salehi analysed the thermal behaviour of the shell-side flow of a shell-and-tube heat exchanger using theoretical and experimental methods. The experimental method provided the effect of the major parameters of the shell-side flow on thermal energy exchange. In the numerical method, besides the effect of the major parameters, the effect of different geometric parameters and Reynolds no $(\mathrm{Re})$ on thermal energy exchange in shell-side flow has been considered. Numerical analysis for six baffle 
spacing's namely $0.20,0.25,0.33,0.50,0.66$, and 1.0 of inside diameter of the shell and five baffle cuts namely $16 \%, 20 \%, 25 \%, 34 \%$, and $46 \%$ of baffle diameter, have been carried out. In earlier numerical analyses, the repetition of an identical geometrical module of exchanger as a calculation domain has been studied. While in this work, as a new approach in current numerical analysis, the entire geometry of shell-and-tube heat exchanger including entrance and exit regions as a calculation domain has been chosen. The results show that the flow and heat profiles vary alternatively between baffles. A shell-and-tube heat exchanger of gas-liquid chemical reactor system has been used in the experimental method. Comparison of the numerical results show good agreement with experimental results of this research and other published experimental results over a wide range of Reynolds numbers (1,000-1,000,000).

A.GopiChand et.al. has proposed a simplified model for the study of thermal analysis of shell-andtubes heat exchangers of water and oil type is proposed. Shell and Tube heat exchangers are having special importance in boilers, oil coolers, condensers, pre-heaters. They are also widely used in process applications as well as the refrigeration and air conditioning industry. The robustness and medium weighted shape of Shell and Tube heat exchangers make them well suited for high pressure operations. This paper shows how to do the thermal analysis by using theoretical formulae and for this they have chosen a practical problem of counter flow shell and tube heat exchanger of water and oil type, by using the data that come from theoretical formulae, they designed a model of shell and tube heat exchanger using Pro-E and done the thermal analysis by using Floefd software and comparing the result that obtained from Floefd software and theoretical formulae. For simplification of theoretical calculations they have also done a Matlab code which is useful for calculating the thermal analysis of a counter flow of water-oil type shell and tube heat exchanger. The result after comparing both was that they were getting an error of 0.023 in effectiveness.

\section{Problem Description}

The thermal performance of a heat exchanger depends upon so many factors. Some of them are thermal conductivities of involved fluids and materials, velocity of flow, turbulence, quality and quantity of the insulation provided, ambient conditions flow conditions etc. To make any exact prediction about the performance of heat exchanger under a set of loading conditions is always a tough job. However by certain testing and experience predictions up to a certain level can be made. The present paper is also an attempt of analyzing the performance of shell and tube type heat exchanger under certain specified loading conditions.

\section{Methodology}

The methodology adopted can be described under following heads:

\subsection{Manual Designing Using Kern's Method ${ }^{1}$}

Shell and tube heat exchangers are designed normally by using either Kern's method or Bell-Delaware method. Kern's method is mostly used for the preliminary design and provides conservative results whereas; the Bell-Delaware method is more accurate method and can provide detailed results. It can predict and estimate pressure drop and heat transfer coefficient with better accuracy. In this paper we have designed a simple counter flow shell and tube type heat exchanger to cool the water from $55^{\circ} \mathrm{C}$ to $45^{\circ} \mathrm{C}$ by using water at room temperature by using Kern's method. The steps of designing are described as follows:

i. First we consider the energy balance to find out the values of some unknown temperature values. Certainly some inputs like hot fluid inlet and outlet temperatures, cold fluid inlet temperature, mass flow rates of the two fluids are needed to serve the purpose. The energy balance equation may be given as:

$\mathrm{Q}=m_{h} c_{p h}\left(t_{h 1}-t_{h 2}\right)=m_{c} C_{p c}\left(t_{c 2}-t_{c 1}\right)$

ii. Then we consider the LMTD expression to find its value:

Where, $\Delta T_{1}=t_{h 1}-t_{c 2}$ and $\Delta T_{2}=t_{h 2}-t_{c 1}$.

$$
L M T D=\frac{(\Delta T 1-\Delta T 2)}{\ln \left(\frac{\Delta T 1}{\Delta T 2}\right)}
$$

iii. Our next step is to calculate the area required of the heat exchanger (on the basis of assumed $U_{0}$ ), number of tubes, tube bundle diameter, diameter of shell and its thickness with the help of following expressions:

$$
\begin{gathered}
\mathrm{A}=\frac{\mathrm{Q}}{\mathrm{U}_{0} \Delta \mathrm{T}} \\
\mathrm{N}_{\mathrm{t}}=\frac{\mathrm{A}}{\pi \mathrm{d}_{\mathrm{t} 0} \mathrm{l}} \\
\mathrm{D}_{\mathrm{b}}=\mathrm{d}_{\mathrm{t} 0}\left(\frac{\mathrm{N}_{\mathrm{t}}}{\mathrm{K}_{1}}\right)^{1 / \mathrm{n}_{1}}
\end{gathered}
$$

The contents under this heading are already accepted by Global Journals Inc. for publication of paper titled as "Steady State Thermal Analysis of Shell and Tube Type Heat Exchanger to Demonstrate the Heat Transfer Capabilities of Various Thermal Materials Using Ansys" by the same authors in GJRE Volume 14 Issue4. 


$$
\begin{gathered}
\mathrm{D}_{\mathrm{i}}=\mathrm{D}_{\mathrm{b}}+\text { additional clearance } \\
\mathrm{D}_{\mathrm{o}}=\mathrm{D}_{\mathrm{i}}+2 \times \text { thicknesss }
\end{gathered}
$$

iv. Then we calculate the proper baffle dimension viz. its diameter, thickness and baffle spacing.

v. Our next step is to find out heat transfer coefficients on the inner and outer surface of the tubes using following correlation:

$\mathrm{Nu}=0.27(R e)^{0.63}\left(P_{r}\right)^{0.36}\left(P_{r} / P_{r w}\right)^{0.25}$

vi. Then by the values obtained by the above equation we calculate the actual value of heat transfer coefficient and check whether the actual value is greater than the assumed one or not.

After rigorous mathematical calculations we have found out following values of interest:

$m_{h}=m_{c}=0.222 \mathrm{~kg} / \mathrm{sec}$

$t_{h 1}=55^{\circ} \mathrm{C}, t_{h 2}=45^{\circ} \mathrm{C}, t_{c 1}=25^{\circ} \mathrm{C}, t_{c 2}=35^{\circ} \mathrm{C}$.

$\mathrm{A}=0.713815 \mathrm{~m}^{2}$

$\mathrm{d}_{\mathrm{t} 0}=23 \mathrm{~mm}$

$\mathrm{d}_{\mathrm{ti}}=20 \mathrm{~mm}$

$\mathrm{N}_{\mathrm{t}}=9$

$\mathrm{D}_{\mathrm{i}}=136 \mathrm{~mm}$

$\mathrm{D}_{\mathrm{o}}=142 \mathrm{~mm}$

Number of baffles $=5$

Diameter of baffles $=136 \mathrm{~mm}$

$\mathrm{B}=300 \mathrm{~mm}$

The first and the last baffles are complete, while the rest three are $25 \%$ cut in order to assure the shell side flow.

\subsection{Steady State Thermal Simulation Using ANSYS}

To ensure the adaptability of the above designing we have taken the shelter of CAD facility. We have generated a software model of shell and tube type heat exchanger using the above derived dimensions. After employing the meshing (a compromise between the accuracy of results and speed of meshing is done) and applying the above stated loading conditions we have solved the model. The material assigned to the shell is stainless steel and that assigned to the tubes and baffles is Copper. The results obtained are as shown below:

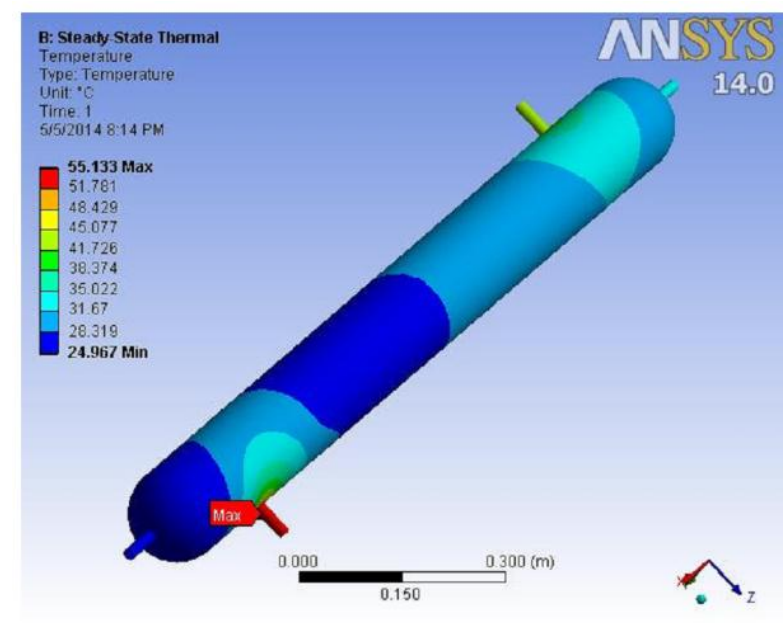

Fig.1. Temperature Distribution After Simulation 


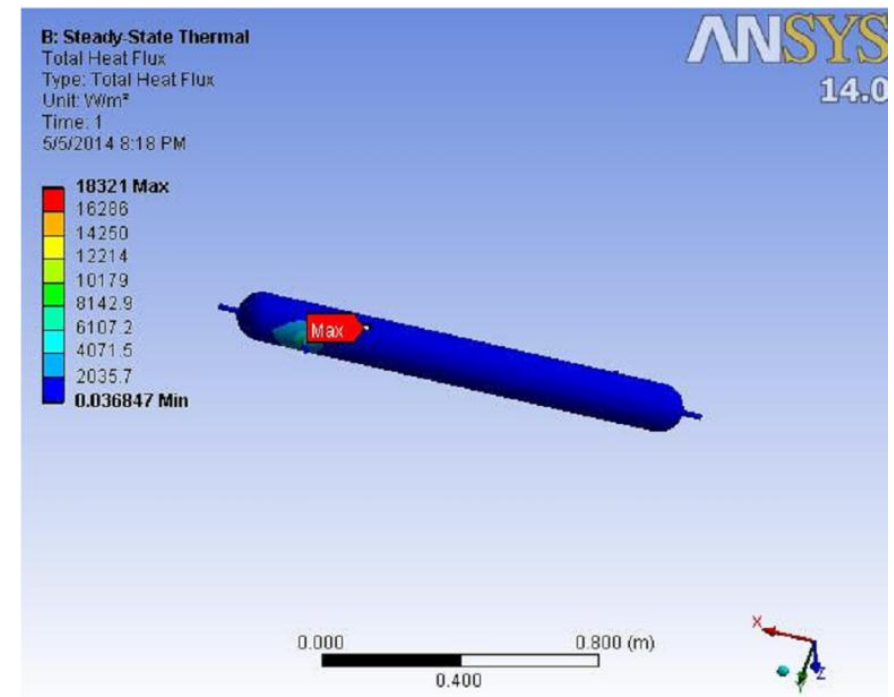

Fig.2. Heat Flux Distribution After Simulation

\subsection{Fabrication of Experimental Setup}

Once we have ensured that our designing is okay and is able to fulfill the required objectives, then we have fabricated an actual working model of derived dimensions and obtained the practical readings to complement our study.

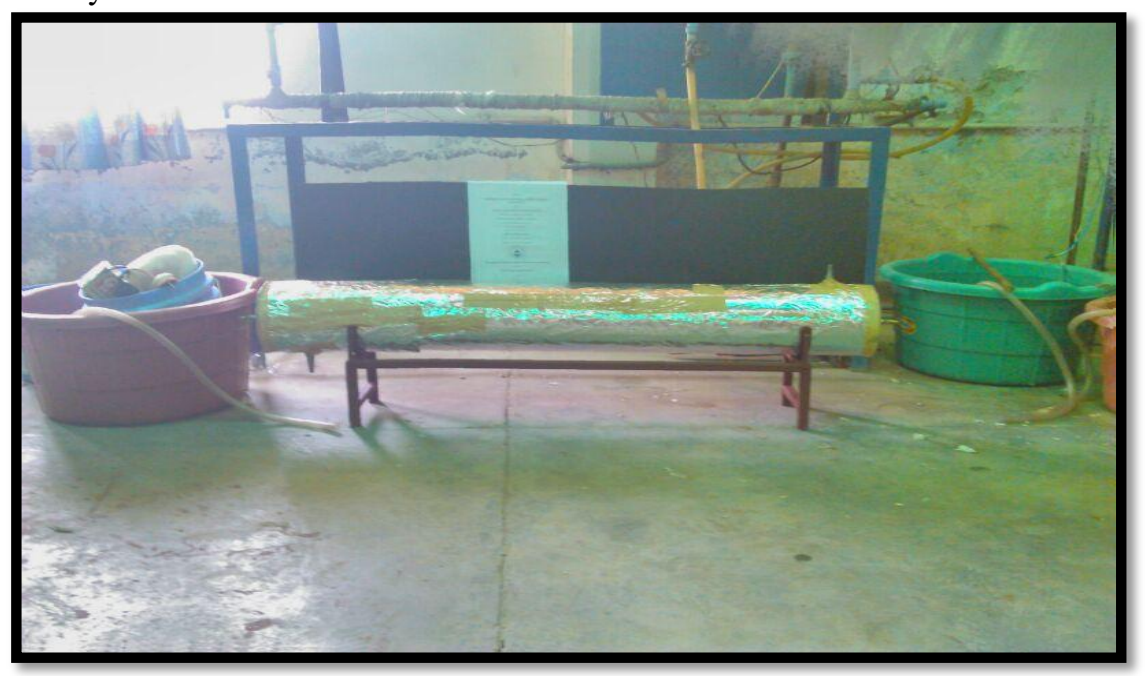

Fig.3. Actual Setup

\subsection{Testing \& Analysis}

Then we have tested so many variations of flow conditions, insulations, turbulence and ambient conditions to test the performance of the heat exchanger under the effect of each.

\section{Results \& Discussions}

\subsection{Practical recordings under Parallel Flow condition}

\subsubsection{Without Insulation}

i. Hot water flowing in shell and cold water flowing in the tubes-

Dated- $11^{\text {th }} \& 12^{\text {th }}$ of April $2014\left(12: 00\right.$ to 4:30 PM), ambient temperature: $33\left({ }^{\circ} \mathrm{C}\right)$

\begin{tabular}{|l|l|l|l|l|l|l|l|}
\hline Serial number & $\begin{array}{l}\text { Hot water } \\
\text { inlet }\left({ }^{\circ} \mathrm{C}\right)\end{array}$ & $\begin{array}{l}\text { Hot water } \\
\text { outlet }\left({ }^{\circ} \mathrm{C}\right)\end{array}$ & $\begin{array}{l}\text { Cold water } \\
\text { inlet }\left({ }^{\circ} \mathrm{C}\right)\end{array}$ & $\begin{array}{l}\text { Cold water } \\
\text { outlet }\left({ }^{\circ} \mathrm{C}\right)\end{array}$ & $\begin{array}{l}\text { Degree of } \\
\text { cooling }\left({ }^{\circ} \mathrm{C}\right)\end{array}$ & $\begin{array}{l}\text { Degree } \\
\text { heating }\left({ }^{\circ} \mathrm{C}\right)\end{array}$ & $\begin{array}{l}\text { Effectiveness } \\
\text { of } \\
\text { exchanger } \\
\text { heat }\end{array}$ \\
\hline 1. & 55.3 & 47.5 & 25.5 & 31.1 & 7.8 & 5.6 & 0.26174 \\
\hline 2. & 55.4 & 47.9 & 24.2 & 30.3 & 7.5 & 6.1 & 0.24038 \\
\hline 3. & 55.0 & 47.5 & 25.0 & 30.0 & 7.5 & 5.0 & 0.25 \\
\hline 4. & 55.3 & 47.5 & 25.5 & 31.1 & 7.8 & 5.6 & 0.26174 \\
\hline 5. & 55.4 & 47.9 & 24.2 & 30.3 & 7.5 & 6.1 & 0.24038 \\
\hline 6. & 55.7 & 48.1 & 24.7 & 30.0 & 7.6 & 5.3 & 0.24516 \\
\hline 7. & 55.3 & 48.3 & 25.2 & 29.3 & 7.0 & 4.1 & \\
\hline
\end{tabular}


ii. Hot water flowing in tubes and cold water flowing in shell-

Dated- 12 ${ }^{\text {th }}$ of April (3:10 PM), ambient temperature: $35\left({ }^{\circ} \mathrm{C}\right)$

\begin{tabular}{|l|l|l|l|l|l|l|l|}
\hline Serial number & $\begin{array}{l}\text { Hot water } \\
\text { inlet }\left({ }^{\circ} \mathrm{C}\right)\end{array}$ & $\begin{array}{l}\text { Hot water } \\
\text { outlet }\left({ }^{\circ} \mathrm{C}\right)\end{array}$ & $\begin{array}{l}\text { Cold water } \\
\text { inlet }\left({ }^{\circ} \mathrm{C}\right)\end{array}$ & $\begin{array}{l}\text { Cold water } \\
\text { outlet }\left({ }^{\circ} \mathrm{C}\right)\end{array}$ & $\begin{array}{l}\text { Degree of } \\
\text { cooling }\left({ }^{\circ} \mathrm{C}\right)\end{array}$ & $\begin{array}{l}\text { Degree of } \\
\text { heating }\left({ }^{\circ} \mathrm{C}\right)\end{array}$ & $\begin{array}{l}\text { Effectiveness of } \\
\text { heat exchanger }\end{array}$ \\
\hline 1. & 55.1 & 46.3 & 24.9 & 30.8 & 8.8 & 5.9 & 0.29139 \\
\hline 2. & 55.3 & 46.7 & 25.2 & 30.7 & 8.6 & 5.5 & 0.28571 \\
\hline
\end{tabular}

4.1.2. With Insulation of Aluminium foil, Foam \& Tape

i. Hot water flowing in shell and cold water flowing in the tubes-

Dated- $15^{\text {th }} \& 16^{\text {th }}$ of April (1:00 to 3:00 PM), ambient temperature: $36\left({ }^{\circ} \mathrm{C}\right)$

\begin{tabular}{|l|l|l|l|l|l|l|l|}
\hline $\begin{array}{c}\text { Serial } \\
\text { number }\end{array}$ & $\begin{array}{l}\text { Hot water } \\
\text { inlet }\left({ }^{\circ} \mathrm{C}\right)\end{array}$ & $\begin{array}{l}\text { Hot water } \\
\text { outlet }\left({ }^{\circ} \mathrm{C}\right)\end{array}$ & $\begin{array}{l}\text { Cold water } \\
\text { inlet }\left({ }^{\circ} \mathrm{C}\right)\end{array}$ & $\begin{array}{l}\text { Cold water } \\
\text { outlet }\left({ }^{\circ} \mathrm{C}\right)\end{array}$ & $\begin{array}{l}\text { Degree of } \\
\text { cooling }\left({ }^{\circ} \mathrm{C}\right)\end{array}$ & $\begin{array}{l}\text { Degree of } \\
\text { heating }\left({ }^{\circ} \mathrm{C}\right)\end{array}$ & $\begin{array}{l}\text { Effectiveness of } \\
\text { heat exchanger }\end{array}$ \\
\hline 1. & 55.1 & 47.4 & 25.1 & 30.5 & 7.7 & 5.4 & 0.25666 \\
\hline 2. & 55.2 & 47.3 & 24.9 & 29.8 & 7.9 & 4.9 & 0.26072 \\
\hline 3. & 55.0 & 46.7 & 25.3 & 29.7 & 8.3 & 4.4 & 0.27946 \\
\hline
\end{tabular}

4.2. Practical Recordings under Counter Flow condition

i. Hot water flowing in shell and cold water flowing in the tubes

4.2.1. With Insulation of Aluminum Foil, Foam \& Tape

Dated- 16 ${ }^{\text {th }}$ of April (3:05 PM), ambient temperature: $38\left({ }^{\circ} \mathrm{C}\right)$

\begin{tabular}{|l|l|l|l|l|l|l|l|}
\hline $\begin{array}{l}\text { Serial } \\
\text { number }\end{array}$ & $\begin{array}{l}\text { Hot water } \\
\text { inlet }\left({ }^{\circ} \mathrm{C}\right)\end{array}$ & $\begin{array}{l}\text { Hot water } \\
\text { outlet }\left({ }^{\circ} \mathrm{C}\right)\end{array}$ & $\begin{array}{l}\text { Cold water } \\
\text { inlet }\left({ }^{\circ} \mathrm{C}\right)\end{array}$ & $\begin{array}{l}\text { Cold water } \\
\text { outlet }\left({ }^{\circ} \mathrm{C}\right)\end{array}$ & $\begin{array}{l}\text { Degree of } \\
\text { cooling }\left({ }^{\circ} \mathrm{C}\right)\end{array}$ & $\begin{array}{l}\text { Degree of } \\
\text { heating }\left({ }^{\circ} \mathrm{C}\right)\end{array}$ & $\begin{array}{l}\text { Effectiveness of } \\
\text { heat exchanger }\end{array}$ \\
\hline 1. & 55.1 & 47.6 & 25.1 & 28.4 & 7.5 & 3.3 & 0.25 \\
\hline 2. & 55.2 & 47.7 & 25.3 & 29.1 & 7.5 & 3.8 & 0.25083 \\
\hline 3. & 55.6 & 48.0 & 25.2 & 31.1 & 7.6 & 5.9 & 0.25 \\
\hline
\end{tabular}

4.2.2. With Insulation of Cotton Wool \& Tape

Dated- 19 ${ }^{\text {th }}$ of April (9:00 AM to 3:00 PM), ambient temperature: $28\left({ }^{\circ} \mathrm{C}\right)$

\begin{tabular}{|l|l|l|l|l|l|l|l|}
\hline $\begin{array}{l}\text { Serial } \\
\text { number }\end{array}$ & $\begin{array}{l}\text { Hot water } \\
\text { inlet }\left({ }^{\circ} \mathrm{C}\right)\end{array}$ & $\begin{array}{l}\text { Hot water } \\
\text { outlet }\left({ }^{\circ} \mathrm{C}\right)\end{array}$ & $\begin{array}{l}\text { Cold water } \\
\text { inlet }\left({ }^{\circ} \mathrm{C}\right)\end{array}$ & $\begin{array}{l}\text { Cold water } \\
\text { outlet }\left({ }^{\circ} \mathrm{C}\right)\end{array}$ & $\begin{array}{l}\text { Degree of } \\
\text { cooling }\left({ }^{\circ} \mathrm{C}\right)\end{array}$ & $\begin{array}{l}\text { Degree of } \\
\text { heating }\left({ }^{\circ} \mathrm{C}\right)\end{array}$ & $\begin{array}{l}\text { Effectiveness of } \\
\text { heat exchanger }\end{array}$ \\
\hline 1. & 55.2 & 46.1 & 26.3 & 32.3 & 9.1 & 6.0 & 0.31487 \\
\hline 2. & 55.1 & 47.4 & 25.2 & 31.3 & 7.7 & 6.1 & 0.25752 \\
\hline 3. & 55.4 & 47.7 & 25.1 & 31.3 & 7.7 & 6.2 & 0.25412 \\
\hline
\end{tabular}

4.2.3. With Insulation of Paper \& Tape

Dated- $20^{\text {th }}$ of April (2:00 to 4:00 PM), ambient temperature: $34\left({ }^{\circ} \mathrm{C}\right)$

\begin{tabular}{|l|l|l|l|l|l|l|l|}
\hline $\begin{array}{l}\text { Serial } \\
\text { number }\end{array}$ & $\begin{array}{l}\text { Hot water } \\
\text { inlet }\left({ }^{\circ} \mathrm{C}\right)\end{array}$ & $\begin{array}{l}\text { Hot water } \\
\text { outlet }\left({ }^{\circ} \mathrm{C}\right)\end{array}$ & $\begin{array}{l}\text { Cold water } \\
\text { inlet }\left({ }^{\circ} \mathrm{C}\right)\end{array}$ & $\begin{array}{l}\text { Cold water } \\
\text { outlet }\left({ }^{\circ} \mathrm{C}\right)\end{array}$ & $\begin{array}{l}\text { Degree of } \\
\text { cooling }\left({ }^{\circ} \mathrm{C}\right)\end{array}$ & $\begin{array}{l}\text { Degree of } \\
\text { heating }\left({ }^{\circ} \mathrm{C}\right)\end{array}$ & $\begin{array}{l}\text { Effectiveness of } \\
\text { heat exchanger }\end{array}$ \\
\hline 1. & 55.2 & 48.4 & 25.4 & 28.5 & 6.8 & 3.1 & 0.22818 \\
\hline 2. & 55.1 & 48.3 & 26.1 & 29.4 & 6.8 & 3.3 & 0.23448 \\
\hline 3. & 55.4 & 48.7 & 25.1 & 29.2 & 6.7 & 4.1 & 0.22112 \\
\hline
\end{tabular}

4.2.4. With Paper Only

Dated- $21^{\text {st }}$ of April (9:00 to 10:30 AM), ambient temperature: $31\left({ }^{\circ} \mathrm{C}\right)$

\begin{tabular}{|l|l|l|l|l|l|l|l|}
\hline $\begin{array}{l}\text { Serial } \\
\text { number }\end{array}$ & $\begin{array}{l}\text { Hot water } \\
\text { inlet }\left({ }^{\circ} \mathrm{C}\right)\end{array}$ & $\begin{array}{l}\text { Hot water } \\
\text { outlet }\left({ }^{\circ} \mathrm{C}\right)\end{array}$ & $\begin{array}{l}\text { Cold water } \\
\text { inlet }\left({ }^{\circ} \mathrm{C}\right)\end{array}$ & $\begin{array}{l}\text { Cold water } \\
\text { outlet }\left({ }^{\circ} \mathrm{C}\right)\end{array}$ & $\begin{array}{l}\text { Degree of } \\
\text { cooling }\left({ }^{\circ} \mathrm{C}\right)\end{array}$ & $\begin{array}{l}\text { Degree of } \\
\text { heating }\left({ }^{\circ} \mathrm{C}\right)\end{array}$ & $\begin{array}{l}\text { Effectiveness of } \\
\text { heat exchanger }\end{array}$ \\
\hline 1. & 55.2 & 49.2 & 23.2 & 27.9 & 6.0 & 4.7 & 0.1875 \\
\hline 2. & 53.2 & 47.1 & 22.2 & 26.7 & 6.1 & 4.5 & 0.19677 \\
\hline 3. & 54.1 & 48.2 & 22.5 & 27.1 & 5.9 & 4.6 & 0.18670 \\
\hline
\end{tabular}

\subsubsection{Without Insulation}

Dated- $21^{\text {st }}$ of April (11:00 AM to 1:00 PM), ambient temperature: $36\left({ }^{\circ} \mathrm{C}\right)$

\begin{tabular}{|l|l|l|l|l|l|l|l|}
\hline $\begin{array}{l}\text { Serial } \\
\text { number }\end{array}$ & $\begin{array}{l}\text { Hot water } \\
\text { inlet }\left({ }^{\circ} \mathrm{C}\right)\end{array}$ & $\begin{array}{l}\text { Hot water } \\
\text { outlet }\left({ }^{\circ} \mathrm{C}\right)\end{array}$ & $\begin{array}{l}\text { Cold water } \\
\text { inlet }\left({ }^{\circ} \mathrm{C}\right)\end{array}$ & $\begin{array}{l}\text { Cold water } \\
\text { outlet }\left({ }^{\circ} \mathrm{C}\right)\end{array}$ & $\begin{array}{l}\text { Degree of } \\
\text { cooling }\left({ }^{\circ} \mathrm{C}\right)\end{array}$ & $\begin{array}{l}\text { Degree of } \\
\text { heating }\left({ }^{\circ} \mathrm{C}\right)\end{array}$ & $\begin{array}{l}\text { Effectiveness of } \\
\text { heat exchanger }\end{array}$ \\
\hline 1. & 56.5 & 50.1 & 26.2 & 30.4 & 6.4 & 4.2 & 0.21122 \\
\hline 2. & 55.2 & 49.3 & 27.2 & 31.4 & 5.9 & 4.2 & 0.21071 \\
\hline 3. & 53.2 & 47.4 & 28.1 & 31.4 & 5.8 & 3.3 & 0.23107 \\
\hline
\end{tabular}

4.2.6. Effect of Increasing Turbulence by Closing the Pump Opening

Dated- $21^{\text {st }}$ of April (1:30 to 4:00 PM), ambient temperature: $38\left({ }^{\circ} \mathrm{C}\right)$

I. $25 \%$ opening Closed

\begin{tabular}{|l|l|l|l|l|l|l|l|}
\hline $\begin{array}{l}\text { Serial } \\
\text { number }\end{array}$ & $\begin{array}{l}\text { Hot water } \\
\text { inlet }\left({ }^{\circ} \mathrm{C}\right)\end{array}$ & $\begin{array}{l}\text { Hot water } \\
\text { outlet }\left({ }^{\circ} \mathrm{C}\right)\end{array}$ & $\begin{array}{l}\text { Cold water } \\
\text { inlet }\left({ }^{\circ} \mathrm{C}\right)\end{array}$ & $\begin{array}{l}\text { Cold water } \\
\text { outlet }\left({ }^{\circ} \mathrm{C}\right)\end{array}$ & $\begin{array}{l}\text { Degree of } \\
\text { cooling }\left({ }^{\circ} \mathrm{C}\right)\end{array}$ & $\begin{array}{l}\text { Degree of } \\
\text { heating }\left({ }^{\circ} \mathrm{C}\right)\end{array}$ & $\begin{array}{l}\text { Effectiveness of } \\
\text { heat exchanger }\end{array}$ \\
\hline 1. & 53.2 & 47.8 & 27.3 & 31.0 & 5.4 & 3.7 & 0.20849 \\
\hline
\end{tabular}




\section{II. $50 \%$ opening Closed}

\begin{tabular}{|l|l|l|l|l|l|l|l|}
\hline $\begin{array}{l}\text { Serial } \\
\text { number }\end{array}$ & $\begin{array}{l}\text { Hot water } \\
\text { inlet }\left({ }^{\circ} \mathrm{C}\right)\end{array}$ & $\begin{array}{l}\text { Hot water } \\
\text { outlet }\left({ }^{\circ} \mathrm{C}\right)\end{array}$ & $\begin{array}{l}\text { Cold water } \\
\text { inlet }\left({ }^{\circ} \mathrm{C}\right)\end{array}$ & $\begin{array}{l}\text { Cold water } \\
\text { outlet }\left({ }^{\circ} \mathrm{C}\right)\end{array}$ & $\begin{array}{l}\text { Degree of } \\
\text { cooling }\left({ }^{\circ} \mathrm{C}\right)\end{array}$ & $\begin{array}{l}\text { Degree of } \\
\text { heating }\left({ }^{\circ} \mathrm{C}\right)\end{array}$ & $\begin{array}{l}\text { Effectiveness of } \\
\text { heat exchanger }\end{array}$ \\
\hline 1. & 50.8 & 43.2 & 27.2 & 31.4 & 7.6 & 4.2 & 0.32203 \\
\hline
\end{tabular}

III. $\quad 75 \%$ opening Closed

\begin{tabular}{|l|l|l|l|l|l|l|l|}
\hline $\begin{array}{l}\text { Serial } \\
\text { number }\end{array}$ & $\begin{array}{l}\text { Hot water } \\
\text { inlet }\left({ }^{\circ} \mathrm{C}\right)\end{array}$ & $\begin{array}{l}\text { Hot water } \\
\text { outlet }\left({ }^{\circ} \mathrm{C}\right)\end{array}$ & $\begin{array}{l}\text { Cold } \\
\text { water inlet } \\
\left({ }^{\circ} \mathrm{C}\right)\end{array}$ & $\begin{array}{l}\text { Cold } \\
\text { water } \\
\text { outlet }\left({ }^{\circ} \mathrm{C}\right)\end{array}$ & $\begin{array}{l}\text { Degree of } \\
\text { cooling } \\
\left({ }^{\circ} \mathrm{C}\right)\end{array}$ & $\begin{array}{l}\text { Degree of } \\
\text { heating } \\
\left({ }^{\circ} \mathrm{C}\right)\end{array}$ & $\begin{array}{l}\text { Effectiveness } \\
\text { of } \\
\text { exchanger }\end{array}$ \\
\hline 1. & 54.8 & 46.8 & 26.2 & 30.4 & 8.0 & 4.2 & 0.27972 \\
\hline
\end{tabular}

Effectiveness of heat exchanger as computed from the software $=\mathbf{0 . 3 3 6}$

Effectiveness of heat exchanger as computed from Kern's method $=0.333$.

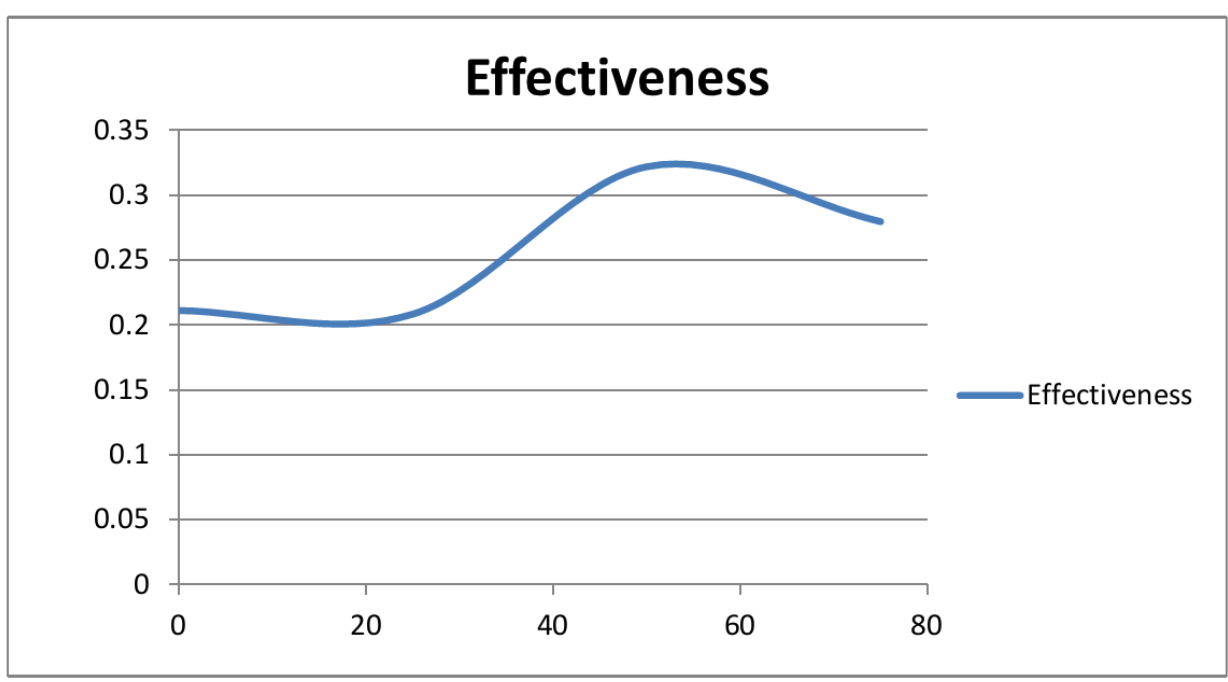

Fig.4. Microsoft Excel Generated Graph Showing Relation Between Percentages Of Pump Opening Closed \& Effectiveness

The conclusions that we have drawn from the analysis of the observed data are as follows:

1. The effectiveness values computed from the software model and that obtained from the actual working model are almost same.

2. When we have tested the heat exchanger under the parallel flow condition without insulation, we have noticed that we are getting a high degree of cooling when the hot water flows in the tubes as compared to the condition in which it has flown through the shell. Also the effectiveness of the heat exchanger is better when the hot fluid flows into the tubes. It means that flowing cold water through the shell side may be beneficial, however sure comments cannot be made over this universally as it is a very special case of equal heat capacity rates of both the fluids.

3. After using the insulation in parallel flow the heat transfer rate increases because the thickness of insulation is well below the critical thickness of insulation.

4. Using the insulation of Aluminium, foam and tape when the flow direction is converted from parallel flow to counter flow, a very minute decrease of about $0.1^{\circ} \mathrm{C}$ in the degree of cooling is observed.

5. Instead of insulation of aluminium, foam and tape when we have employed the insulation of cotton wool and tape under counter flow condition a significant increase in the heat transfer rate as well as in the effectiveness of the heat exchanger is obtained.

6. Instead of cotton wool and tape when a minute layer of paper of about $1.5 \mathrm{~mm}$ thickness along with tape is used as an insulator then we have observed that degree of cooling has decreased so much from the range of $7.7-9.1{ }^{\circ} \mathrm{C}$ to the range of $6.7-6.8^{\circ} \mathrm{C}$.

7. Then we have removed the tape and tested under the insulation of paper only we have observed that the degree of cooling have now decreased from $6.7-6.8^{\circ} \mathrm{C}$ to $5.9-6.1^{\circ} \mathrm{C}$.

8. At this stage we were unable to find the reason of continuous decrease in heat transfer after removal of insulation. We were surprised because without insulation the heat exchanger in parallel flow was giving about $7.5^{\circ} \mathrm{C}$, and after the initial employment of insulation of aluminium foil, foam and tape it has cooled up to $8.3^{\circ} \mathrm{C}$. hence we were expecting that increasing the thickness of insulation will give us about the 9.0 to $9.5^{\circ} \mathrm{C}$ degree of cooling in counter flow condition. But when we tested carefully the internal parts of the heat exchanger we 
found that it was happening due to fouling. Actually in Indian subcontinent especially in summer season there is huge amount of dust accumulated in the surroundings. It is somehow natural and also due to construction works, dust storms, high velocity winds etc. we were keeping water in the open space hence it was continuously contaminated by dust particles. Moreover the water which we were using was not of the very great quality. And sometimes by mistake we have also not poured the water out of the heat exchanger; hence the dirty water was continuously in contact with the body parts of the heat exchanger for the period of approximately 200 hours. Such a time is sufficient in Indian subcontinent for scale formation in the metallic body. Hence it was inevitable to stop the effect of the same on the observations.

9. Again to remove our suspicion that is there anything else which is affecting the performance of heat exchanger we had tested the exchanger without insulation in the counter flow condition and found the degree of cooling to be about $6{ }^{\circ} \mathrm{C}$ only. This has been decreased from the initial value of about $7.5^{\circ} \mathrm{C}$.

10. Also it can be said that the insulation was doing its work satisfactorily but it was the scale formation due to which the heat transfer rate had been decreasing.

11. Again we wanted to test the equipment under increased turbulence condition because it is universally accepted that if we increase the turbulence the rate of heat transfer between the interacting fluids increases. To do this we have obstructed the pump opening. As the mass flow rate is constant if we would decrease the area of pump mouth opening the velocity will automatically increase. This increase in the velocity is related with the increase in the turbulence and consequently an increase in the heat transfer rate.

12. The observations recorded show that when the pump opening has been closed to $25 \%$ the degree of cooling is $5.4^{\circ} \mathrm{C}$. Again when the pump opening is closed up to $50 \%$ the degree of cooling had increased to $7.6^{\circ} \mathrm{C}$. Now we have closed the mouth of the pump to an extent of about $75 \%$, the degree of cooling had been found to be $8.0^{\circ} \mathrm{C}$.

13. All these readings have been obtained without removal of scaling. Hence it can be surely said that by increasing the turbulence the effectiveness of heat exchanger can be increased. Another important observation is that due to scale formation the heat absorbed by cold fluid has been decreased significantly. It can be observed that the degree of heating of cold fluid has been decreased from about $6.0^{\circ} \mathrm{C}$ in the case of without scale formation to a value of about $3.8^{\circ} \mathrm{C}$.

14. The readings under the varied opening condition and the graph shown in fig.4 depict that the effectiveness of the heat exchanger is maximum at 50\% pump opening. The value of the effectiveness of heat exchanger decreases from full opening to $75 \%$ of mouth opening, then it increases from $75 \%$ of mouth opening to $50 \%$ of mouth opening and after attaining its peak at $50 \%$ pump opening value again decreases up to the condition of $25 \%$ pump opening.

15. The ambient temperature has also been recorded while taking the readings to see its impact over the performance of heat exchanger; however it is very difficult to explain the effect of ambient conditions over heat exchanger's performance and also nothing very significant effect has also been observed in this regard except that the morning hours are suitable for manual handling.

16. One more thing which is to be noticed is that the degree of heating and degree of cooling of the cold fluid and the hot fluid respectively are found to be unequal in each and every recording, which is contrary to what is assumed in the assumptions of the derivation of heat exchanger's effectiveness. Hence the expression of effectiveness also needs some improvements.

\section{Error Analysis}

The work done by any level of perfection never can be errorless. Error analysis is a very significant part in each and every project. It gives an overview of the mistakes that have been done in the present work so that in the future it may not be repeated and also the project completers may analyze that what better can be done to achieve more perfection. In this paper we have tried to be error free as far as possible, still the $100 \%$ has been probably made for GOD only. The error associated with our works according to us can be described in the following points:

\subsection{Errors in manual designing}

Any design is based on certain set of standards, values and observations. The degree of accuracy of designing depends upon the accuracy of data available. As there is also a limit of the accuracy of data hence same is the case of designing. In this paper we have assumed certain things like the pump is working with full efficiency, the thermo-physical properties are correct and steps or equations involved does not bear any discrepancies. However it may be true up to only a certain level.

\subsection{Errors in Software Analysis}

During software analysis we have performed finite element analysis by meshing the model. However to have very fine meshing very high micro processor speeds are required. In industries therefore several super 
computers and softwares like HYPERMESH etc. are used. However in this paper a compromise has been made between the computer speed and accuracy of data. Moreover the results obtained from simulation also are controlled by the accuracy of the environment provided by software. The error associated with the steady state thermal simulation due to inaccuracy of finite elemental analysis as obtained from ANSYS is as shown below:

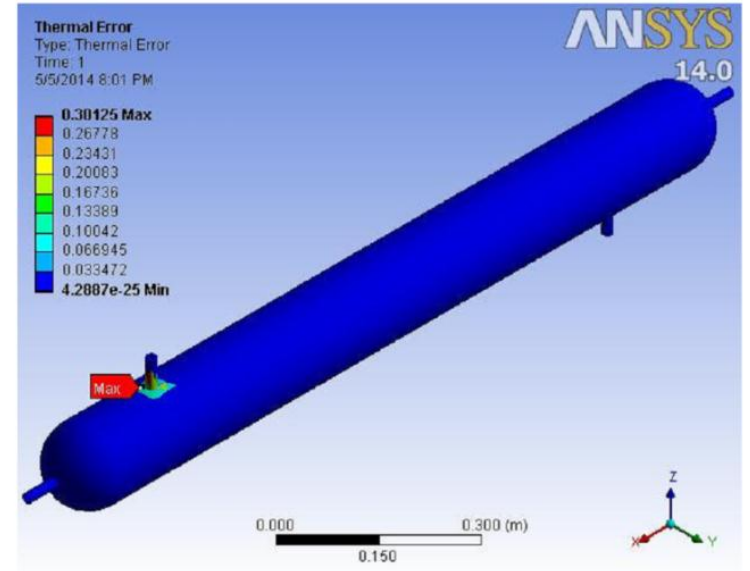

\subsection{Errors in Fabrication}

Fig.5. Thermal Error Obtained From Simulation

The setup used for observation and testing has also been fabricated using machinery. Hence the accuracy of fabrication depends upon accuracy of machines and machining processes, labour skills, and other operating conditions like vibration, chattering etc. The error associated with the fabrication processes may be guessed by the fact that we have noticed the leakage on the first testing of the setup and after correction it was good to use.

\subsection{Errors in Observations Recorded}

The accuracy of observation depends upon the instruments used for measurement. For example in this analysis the accuracy of temperatures recorded will be dependent upon the accuracy of thermometer and its sensors. Moreover the observations may also be incorrect due to any manual error however the chances of such happenings in this paper are very rare.

\subsection{Errors in the analysis of Observed data}

Again the accuracy of the analysis depends upon the accuracy of the mathematical expressions, charts and techniques used for analysis purpose.

\subsection{Accuracy of Conclusion}

The accuracy of the conclusion derived on the basis of the above study depends upon the accuracy of all the steps involved in this analysis. A combined effect of all the errors in association shall be reflected over the results.

\section{Conclusion}

On the basis of above study it is clear that a lot of factors affect the performance of the heat exchanger and the effectiveness obtained by the formulas depicts the cumulative effect of all the factors over the performance of the heat exchanger. It may be said that the insulation is a good tool to increase the rate of heat transfer if used properly well below the level of critical thickness. Amongst the used materials the cotton wool and the tape have given the best values of effectiveness. Moreover the effectiveness of the heat exchanger also depends upon the value of turbulence provided. However it is also seen that there does not exists direct relation between the turbulence and effectiveness and effectiveness attains its peak at some intermediate value. The ambient conditions for which the heat exchanger was tested do not show any significant effect over the heat exchanger's performance.

\section{References:}

[1]. A.O. Adelaja, S. J. Ojolo and M. G. Sobamowo, "Computer Aided Analysis of Thermal and Mechanical Design of Shell and Tube Heat Exchangers", Advanced Materials Vol. 367 (2012) pp 731-737 ( ) (2012) Trans Tech Publications, Switzerland.

[2]. Yusuf Ali Kara, Ozbilen Guraras, "A computer program for designing of Shell and tube heat exchanger", Applied Thermal Engineering 24(2004) 1797-1805. 
[3]. Rajagapal THUNDIL KARUPPA RAJ and Srikanth GANNE, "Shell side numericalanalysis of a shell and tube heat exchanger considering the effects of baffle inclination angle on fluid flow", Thundil Karuppa Raj, R., et al.: Shell Side Numerical Analysis of a Shell and Tube Heat Exchanger,THERMAL SCIENCE: Year 2012, Vol. 16, No. 4, pp. 1165-1174.

[4]. S. Noie Baghban, M. Moghiman and E. Salehi, " Thermal analysis of shell-side flow of shell-and tube heat exchanger using experimental and theoretical methods" (Received: October 1, 1998 - Accepted in Revised Form: June 3, 1999).

[5]. A.GopiChand, Prof.A.V.N.L.Sharma, G.Vijay Kumar, A.Srividya, " Thermal analysis of shell and tube heat exchanger using mat lab and floefd software", Volume: 1 Issue: 3276 - 281, ISSN: $2319-1163$.

[6]. Hari Haran, Ravindra Reddy and Sreehari, "Thermal Analysis of Shell and Tube Heat ExChanger Using C and Ansys" , International Journal of Computer Trends and Technology (IJCTT) - volume 4 Issue 7-July 2013.

[7]. Donald Q.Kern. 1965. Process Heat transfer (23 $3^{\text {rd }}$ printing 1986). McGraw-Hill companies.ISBN 0-07-Y85353-3.

[8]. Richard C. Byrne Secretary. 1968. Tubular Exchanger Manufacturers Association, INC. (8th Edition). 25 North Broadway Tarrytown, New York 10591.

[9]. R.H Perry. 1984. Perry's Chemical Engineer's Handbook (6th Edition ed.). McGraw-Hill. ISBN 0-07-049479-7.

[10]. Ender Ozden, Ilker Tari, Shell Side CFD Analysis of A Small Shell And Tube Heat Exchanger, Middle East Technical University, 2010 . 